\section{PENGARUH TERAPI BEKAM BASAH TERHADAP PERUBAHAN SKALA NYERI PADA PASIEN MIGRAIN}

\section{EFFECT OF WET BEKAM THERAPY ON PAIN SCALES CHANGE IN MIGRAIN PATIENTS}

\author{
Mulia Mayangsari*) \\ Indriyarti Harun*) \\ *) Sekolah Tinggi Ilmu Kesehatan (STIKes) \\ Ngudia Husada Madura
}

The research design used was Experimental with Kunsekutive Sampling technique. The population in this study were patients who had migraine in Noreh village. The working area of Puskesmas Sreseh was 18 respondents and the result was analyzed using Shapiro Wilk and Wilcoxon test.

The results of the study in migraine patients can be seen that the mean pretest scale of migraine pain scale is 4.67 whereas, for the mean posttest of migraine pain scale is 2.22. In the pretest of migraine pain scale the minimum value found is 4 whereas, the maximum value is 6. While in posttest skalanyeri migraine the minimum value found is 1 whereas, the maximum value is 3 .

In the Shapiro Wilk analysis showed that there were differences in the scale of migraine pain before and after wet bruise therapy. In the Wilcoxon analysis comparing migraine patients, a p-value of 0,000 indicated that there was an effect of wet-brushing therapy on changes in the pain scale.

To health workers and educational institutions are expected to use wet brewing therapy as a complementary alternative and as a non-pharmacological treatment that can reduce the scale of pain.

Keywords: Migraine, Pain, Cupping

Correspondence : Mulia Mayangsari, Jl. R.E. Martadinata Bangkalan, Indonesia.

\section{PENDAHULUAN}

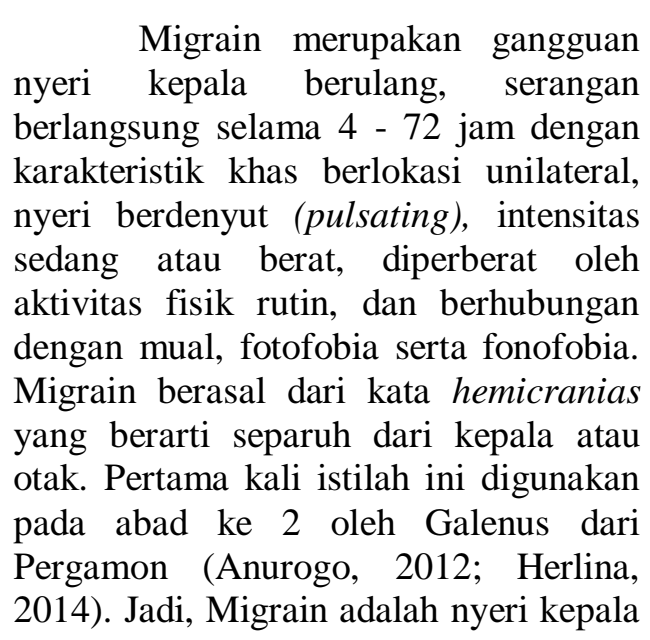

berulang-ulang berlangsung selama kurang lebih 4 - 72 jam menyerang pada sisi kepala dengan kualiatas nyeri yang bervariasi.

Bekam ada dua yaitu bekam kering dan bekam basah. Bekam kering adalah menghisab permukaan kulit dan memijat tempat sekitarnya dengan gelas tekanan negatif, tanpa mengeluarkan darah kotor. Bekam kering baik bagi orang yang tidak tahan suntikan jarum dan takut melihat darah. Kulit yang dibekam akan tampak merah kehitamhitaman selama 3 hari atau akan kelihatan memar selama 1 atau 2 pekan. Bekam ini sedotannya hanya sekali dan 
dibiarkan selama 5 - 10 menit. Bekam ini berkhasiat untuk mengurangi sakit secara darurat atau digunakan untuk meringankan nyeri pada punggung karena sakit rheumatik, juga penyakitpenyakit nyeri punggung. Bekam kering bermanfaat juga untuk terapi penyakit paru, radang ginjal, pembengkakan pada liver atau radang selaput jantung, radang urat syaraf, radang sumsum tulang belakang, masuk angin, wasir, dan lainlain. Terdapat dua teknik bekam kering yang dapat dipraktekkan untuk tempat tertentu yaitu bekam luncur dan bekam tarik. Sedangkan, Bekam basah adalah pertama kita melakukan bekam kering, kemudian kita melukai permukaan kulit dengan jarum tajam (lancet) atau senyatan pisau steril (surgical blade) lalu disekitarnya dihisap dengan alat cupping set dan hand pump untuk mengeluarkan darah kotor dari dalam tubuh. Lamanya setiap hisapan 3 sampai 5 menit, dan maksimal 9 menit, lalu dibuang darah kotornya. Penghisapan tidak lebih dari 7 kali hisapan. Darah kotor berupa darah merah pekat dan berbuih. Bekasnya berupa kulit yang lebam akan hilang 3 hari kemudian setelah diolesi minyak habbah sauda' atau minyak zaitun dan selama 3 jam setelah dibekam kulit yang lebam itu tidak boleh disiram air. Jarak waktu pengulangan bekam pada tempat yang sama adalah 4 minggu. Bekam basah berkhasiat untuk berbagai penyakit, terutama penyakit yang terkait dengan terganggunya sistem peredaran darah di tubuh. Kalau bekam kering dapat menyembuhkan penyakit-penyakit yang lebih ringan, maka bekam basah dapat menyembuhkan penyakit-penyakit yang lebih berat, akut, kronis ataupun yang degeneratif, seperti darah tinggi, kanker, asam urat, diabetes militus (kencing manis), kolesterol, dan osteoporosis (Pusponegoro, 2009 dalam Widada, 2011).

Bekam basah adalah
pengobatan komplementer,
telah
menurunkan nyeri pada 66\% pasien
nyeri kepala (Ahmadi, 2008). Pada
penenelitian Cao, et al. (2010)

menemukan bahwa $58 \%$ pasien memilih bekam basah diantara metode bekam lainnya \& 38,43\% pasien yang berobat dalam kondisi nyeri. Penggunaan terapi bekam basah lebih banyak diminati pasien, karena pasien merasa nyaman setelah dibekam. Survey Balai Pusat Statistik (BPS) tahun 2014 prosentase penduduk yang menggunakan fasilitas rawat inap 2,5\%, berobat jalan 49,29\%, menggunakan obat tradisional 20,99\%. Hal ini menunjukkan bahwa minat masyarakat Indonesia terhadap pengobatan di rumah (rawat jalan) dan pengobatan tradisional cukup tinggi. Bila penelitian ini terbukti, maka dapat dijadikan rujukan, bahwa bekam basah dapat dipilih menjadi terapi komplementer untuk pasien migrain.

Secara global, telah diperkirakan bahwa prevalensi di antara orang dewasa gangguan sakit kepala saat ini (gejala setidaknya sekali dalam satu tahun) adalah 47\%. Setengah sampai tiga perempat dari orang dewasa berusia 20 - 40 tahun di dunia telah memiliki sakit kepala sebelumnya dan di antaranya, lebih dari 10\% telah melaporkan migrain. Setiap bulannya, sakit kepala mempengaruhi 1,7 - 4\% dari populasi orang dewasa di dunia. Sakit kepala adalah masalah di seluruh dunia, mempengaruhi orang dari segala usia, ras tingkat pendapatan dan wilayah geografis. Paling sering dimulai pada masa pubertas dan sebagian besar mempengaruhi orang-orang berusia antara 20 dan 40 tahun (WHO, 2010 dalam Rahma, 2012).

Migrain dialami oleh lebih dari 28 juta orang di seluruh dunia. Prevalensinya kurang lebih mencapai $10 \%$. Beberapa study menunjukkan bahwa prevalensi seumur hidup (lifetime prevalence) pada wanita lebih banyak dari pada pria sebesar $25 \%$. Sedangkan, pada pria hanya sebesar $8 \%$. Usia penderita terbanyak sekitar 20 - 40 tahun. Negara Amerika telah mengalami kerugian sebesar 5,6 - 17,2 milyar dollar Amerika akibat hilangnya waktu kerja \& 
produktivitas pekerjanya yang mengalami migrain.

Berdasarkan data yang diperoleh dari Puskesmas Sreseh Kabupaten Sampang, pasien yang mengalami migrain diperoleh data tiga bulan terakhir ditahun 2016 jumlah pasien migrain di bulan Agustus 10 pasien, pada bulan September tercatat 15 pasien migrain, dan pada bulan Oktober tercatat 18 pasien migrain. Dapat disimpulkan bahwa jumlah pasien migrain di Desa Noreh Wilayah Kerja Puskesmas Sreseh Kabupaten Sampang mengalami peningkatan setiap bulannya.

Faktor-faktor yang dapat memicu terjadinya migrain makanan yaitu, makanan yang mengandung keju, alkohol, makanan yang mengandung monosodium glutamate, coklat, kacang, alpukat, jeruk, bawang, ikan, daging. Obat-obatan yaitu, vasodilatator seperti nitrogliserin isosorbide dinitratine, hormon seperti kontrasepsi oral estrogen, histamine-2 blockers seperti cimetidine ranitidine, antibiotik seperti trimethoprim-sulfa. Gaya hidup yaitu, puasa, stress dan ketergantungan kafein. Migrain juga dapat dipicu oleh perubahan musim dan tempat yang tinggi seperti tempat pendakian gunung (Tarwoto, 2013).

Migrain atau sakit kepala sebelah sebenarnya faktor penyebabnya belum diketahui secara pasti. Namun diperkirakan jenis sakit kepala ini disebabkan karena adanya hiperaktifitas impuls listrik otak yang meningkatkan aliran darah di otak sehingga terjadi pelebaran pembuluh darah otak serta proses inflamasi (luka radang). Sering kali migrain terlihat sepele bagi sebagian orang, namun sesungguhnya menyimpan suatu potensi yang mengancam bagi penderitanya antara lain beresiko akan terkena stroke, penyakit kardiovakular, diabetes, tekanan darah tinggi, dan kolesterol tinggi. Migrain bukan lagi penyakit yang terisolasi dan merupakan gejala tunggal, namun berefek domino pada penyakit lainnya. Hal ini tentu menjadi sebuah berita yang cukup untuk diperhatikan.
Dengan serangan yang umumnya berulang, penderita migrain akan merasakan nyeri dan berdenyut seperti dipukul dan terasa seakan menyiksa tetapi migrain dapat datang dengan tibatiba (Zulfikri, 2015).

Migrain dapat diatasi dengan terapi farmakologis dan non farmakologis. Pada terapi farmakologis, dibagi dalam dua bagian, yaitu terapi abortif dan terapi profilaksis. Terapi abortif bertujuan untuk menangani serangan nyeri akut. Terapi ini pertama adalah sebagai obat abortif nonspesifik untuk serangan ringan sampai sedang atau serangan berat atau berespons baik terhadap obat yang sama, dapat dipakai golongan analgesik atau NSAID yang dijual bebas. Terapi ini kedua adalah sebagai obat abortif spesifik apabila tidak responsif terhadap analgesik dan NSAID (obat abortif nonspesifik) seperti golongan triptan dan dihidroergotamin (DHE). Golongan triptan digunakan pada migrain sedang atau migrain ringan sampai sedang yang tidak responsif terhadap analgesik atau NSAID (Kurniawan, 2015). Sedangkan non farmakologis salah satunya dengan berbaring ditempat gelap, pijat atau cium minyak angin, dan terapi bekam basah. Diantara terapi non farmakologis tersebut yang lebih bermanfaat yaitu terapi bekam basah. Terapi bekam basah bertujuan untuk membersihkan darah dari racun-racun makanan dan dapat meningkatkan aktivitas syaraf tulang belakang (vertebra), mengatasi gangguan tekanan darah yang tidak normal dan pengapuran pada pembuluh darah (Arteriosis), menghilangkan pusingpusing, memar dibagian kepala, wajah, migrain, dan sakit gigi, menghilangkan kejang-kejang dan kram pada otot, memperbaiki permeabilitas pembuluh darah, meringankan rasa sakit dan mengurangi penumpukan darah (Widada, 2011).

Bekam diharapkan menjadi obat alternatif tanpa efek samping seperti obat-obatan tersebut untuk 
menghilangkan atau menurunkan nyeri dikepala. Selain itu diharapkan hasil penelitian ini juga dapat menunjang anjuran Nabi Muhammad SAW kepada umatnya untuk berbekam oleh karena itu peneliti tertarik untuk melakukan penelitian mengenai bekam basah terhadap pasien migrain (Yanti, 2012).

Proses pemberian terapi bekam basah terhadap penurunan skala nyeri pada migrain dapat mengendalikan serotonin sehingga tidak terjadi peradangan pada syaraf kelima, sakit kepala berkurang, sehingga skala nyerinya juga akan mengalami penurunan (Kurniawan, 2015).

\section{METODE PENELITIAN}

Pada penelitian ini desain penelitian yang digunakan adalah "Pra Eksperimental" dengan pendekatan rancangan pra-pascates dalam satu kelompok (One-group pra-post test design) yaitu mengungkapkan hubungan sebab akibat dengan cara melibatkan satu kelompok subjek. Kelompok subjek diobservasi sebelum dilakukan intervensi, kemudian diobservasi lagi setelah intervensi (Nursalam, 2013).

Pada penelitian ini populasi yang digunakan adalah 18 pasien migrain yang berada di Desa Noreh wiyah kerja Puskesmas Sreseh dengan sampel 18 pasien migrain. Dalam penelitian ini tekhnik pengambilan sampel menggunakan kunsekutive sampling yaitu pengambilan sample diambil dari sampel yang memenuhi kriteria (Sujarweni, 2014).

Data dikumpulkan dengan menggunakan observasi skala nyeri pretest dan postes. Diuji dengan uji statistik Shapiro Wilk dan Wilcoxon.

\section{HASIL PENELITIAN}

\section{Data Umum dan Data Khusus}

Tabel 1 Distribusi frekuensi reponden yang mengalami migrain berdasarkan jenis kelamin

\begin{tabular}{ccc}
\hline Jenis kelamin & Frekuensi & Persentase $\%$ \\
\hline Laki-laki & 7 & 38,89 \\
Perempuan & 11 & 61,11 \\
\hline Total & 18 & 100 \\
\hline
\end{tabular}

Sumber Data: Perolehan Data di

Lapangan

Dari tabel 1 menunjukkan bahwa pada pasien migrain yang mendapatkan terapi bekam basah sebagian besar adalah jenis kelamin perempuan yaitu berjumlah 11 orang responden $(61,11 \%)$, sedangkan yang berjenis kelamin laki laki yaitu berjumlah 7 orang responden $(38,89 \%)$.

Tabel 2 Distribusi frekuensi responden yang mengalami migrain berdasarkan usia.

\begin{tabular}{ccc}
\hline Usia & Frekuensi & $\begin{array}{c}\text { Persentase } \\
\%\end{array}$ \\
\hline $20-25$ & 7 & 38,89 \\
$25-30$ & 11 & 61,11 \\
$31-35$ & 0 & 0 \\
\hline Total & 73 & 100 \\
\hline Sumber Data: & Perolehan Data di \\
Lapangan \\
Dari tabel 2 & menunjukkan \\
bahwa pada pasien migrain yang \\
mendapatkan terapi bekam basah \\
sebagian besar berada dikelompok usia \\
yaitu 26-30 tahun sebesar 61,11\% \\
dengan jumlah responden 11.
\end{tabular}

Tabel 3 Distribusi frekuensi reponden yang mengalami migrain berdasarkan pekerjaan.

\begin{tabular}{ccc}
\hline Pekerjaan & Frekuensi & Persentase \% \\
\hline Belum bekerja & 8 & 44,44 \\
Ibu Rumah & 2 & 11,11 \\
tangga & & \\
Swasta & 2 & 11,11 \\
Nelayan & 3 & 16,66 \\
Petani & 3 & 16,66 \\
\hline Total & 18 & 100 \\
\hline
\end{tabular}

Sumber Data: Perolehan Data di Lapangan

Dari tabel 3 menunjukkan bahwa pada pasien migrain yang 
mendapatkan terapi bekam basah hampir setengahnya adalah dengan pekerjaan belum bekerja yaitu sebanyak 8 orang responden $(44,44 \%)$.

Tabel 4 Distribusi frekuensi pretest skala nyeri.

\begin{tabular}{|c|c|c|}
\hline Usia & Frekuensi & $\begin{array}{l}\text { Persentase } \\
\%\end{array}$ \\
\hline 1 & 4 & Sedang \\
\hline 2 & 6 & Sedang \\
\hline 3 & 5 & Sedang \\
\hline 4 & 4 & Sedang \\
\hline 5 & 4 & Sedang \\
\hline 6 & 4 & Sedang \\
\hline 7 & 6 & Sedang \\
\hline 8 & 5 & Sedang \\
\hline 9 & 5 & Sedang \\
\hline 10 & 5 & Sedang \\
\hline 11 & 4 & Sedang \\
\hline 12 & 6 & Sedang \\
\hline 13 & 4 & Sedang \\
\hline 14 & 4 & Sedang \\
\hline 15 & 5 & Sedang \\
\hline 16 & 5 & Sedang \\
\hline 17 & 4 & Sedang \\
\hline 18 & 4 & Sedang \\
\hline Total & 73 & 100 \\
\hline Ringan & 0 & 0 \\
\hline Sedang & 18 & $100 \%$ \\
\hline Berat & 0 & 0 \\
\hline \multicolumn{3}{|c|}{$\begin{array}{l}\text { Berdasarkan tabel } 4 \text { diatas } \\
\text { dapat diketahui responden yang } \\
\text { sebelum dilakukan tindakan terapi } \\
\text { bekam basah seluruhnya memiliki } \\
\text { skala nyeri dalam kategori sedang } \\
(100 \%) \text { dengan jumlah responden } 18 .\end{array}$} \\
\hline \multicolumn{3}{|c|}{$\begin{array}{l}\text { Tabel } 5 \text { Distribusi frekuensi postest } \\
\text { skala nyeri. }\end{array}$} \\
\hline Usi & Frekuer & $\begin{array}{c}\text { Persentase } \\
\%\end{array}$ \\
\hline
\end{tabular}

\begin{tabular}{|c|c|c|}
\hline 1 & 2 & Ringan \\
\hline 2 & 2 & Ringan \\
\hline 3 & 2 & Ringan \\
\hline 4 & 2 & Ringan \\
\hline 5 & 2 & Ringan \\
\hline 6 & 1 & Ringan \\
\hline 7 & 1 & Ringan \\
\hline 8 & 1 & Ringan \\
\hline 9 & 3 & Ringan \\
\hline 10 & 3 & Ringan \\
\hline 11 & 3 & Ringan \\
\hline 12 & 2 & Ringan \\
\hline 13 & 2 & Ringan \\
\hline 14 & 2 & Ringan \\
\hline 15 & 3 & Ringan \\
\hline 16 & 3 & Ringan \\
\hline 17 & 3 & Ringan \\
\hline 18 & 3 & Ringan \\
\hline $100 \%$ Ringan & & \\
\hline $\begin{array}{ll} & \text { Sedang } \\
0 & \end{array}$ & & \\
\hline Berat & & \\
\hline
\end{tabular}

Berdasarkan tabel 5 diatas dapat diketahui responden yang sesudah dilakukan tindakan terapi bekam basah seluruhnya memiliki skala nyeri dalam kategori sedang (100\%) dengan jumlah responden 18.

Tabel 6 Distribusi frekuensi perubahan skala nyeri pada pasien migrain sebelum dan sesudan di berikan terapi bekam basah.

\begin{tabular}{ccccc}
\hline & $\begin{array}{c}\text { Fre } \\
\text { kuensi }\end{array}$ & $\begin{array}{c}\text { Perse } \\
\text { ntase } \\
(\%)\end{array}$ & $\begin{array}{c}\text { Fre } \\
\text { kuensi }\end{array}$ & $\begin{array}{c}\text { Persentase } \\
(\%)\end{array}$ \\
\hline $\begin{array}{c}\text { Ringa } \\
\mathrm{n}\end{array}$ & 0 & 0 & 18 & $100 \%$ \\
\hline $\begin{array}{c}\text { Sedan } \\
\mathrm{g}\end{array}$ & 18 & $100 \%$ & 0 & 0 \\
\hline Berat & 0 & 0 & 0 & 0 \\
\hline$\sum$ & 18 & $100 \%$ & 18 & $100 \%$ \\
\hline $\begin{array}{c}\text { Uji } \\
\text { Wilcoxo } \\
n\end{array}$ & & $\begin{array}{c}\mathrm{P}= \\
0,00\end{array}$ & & $0,05=$ \\
\hline
\end{tabular}


Berdasarkan tabel 6 diatas dapat diketahui bahwa pretest skala nyeri migrain seluruhnya termasuk kategori sedang (100\%) dengan jumlah responden 18. Sedangkan untuk hasil postest skala nyeri migrain seluruhnya termasuk dalam kategori ringan (100\%) dengan jumlah responden 18. Hal ini memperkuat bahwa terapi bekam basah dapat menurunkan skala nyeri pada pasien migrain. Dari hasil uji beda menggunakan Wilcoxon Signed Ranks didapatkan hasil $\mathrm{p}$ value 0,00 kurang dari $\alpha$ 0,05. Sehingga Ho ditolak dan $\mathrm{H} 1$ diterima yang mempunyai arti bahwa ada pengaruh terapi bekam basah terhadap penurunan skala nyeri pada pasien migrain.

\section{PEMBAHASAN}

\section{Perbedaan Skala Nyeri pada pasien migrain sebelum dan sesudah diberikan Terapi Bekam Basah di Desa Noreh Wilayah Kerja Puskesmas Sreseh}

Berdasarkan hasil penelitian di Desa Noreh Wilayah Kerja Puskesmas Sreseh didapatkan perbedaan antara nilai pre dan post pada pasien migrain. Pada pasien migrain dapat diketahui bahwa pretest skala nyeri migrain seluruhnya termasuk kategori sedang (100\%) dengan jumlah responden 18. Sedangkan untuk hasil postest skala nyeri migrain seluruhnya termasuk dalam kategori ringan $(100 \%)$ dengan jumlah responden 18.

Fakta diatas sejalan dengan teori yang diungkapkan oleh Widada (2011), Bekam basah berkhasiat untuk berbagai penyakit, terutama penyakit yang terkait dengan terganggunya sistem peredaran darah di tubuh. Dan hasil penelitian medis modern telah mendapatkan bukti yang menakjubkan para ahli, yaitu bahwa bekam ternyata hanya mengambil bagian darah yang rusak saja yaitu selsel darah merah yang abnormal dan sampah keratin, sedangkan sel darah yang sehat tetap didalam tubuh.

Menurut Sharaf (2012), Bekam bisa mengendalikan kadar serotonin sehingga mencegah terjadinya peradangan pada syaraf kelima (trigeminanerve), bekam juga dapat mengendalikan kadar serotonin maka ia juga mencegah terjadinya penyempitan arteri karotis internal. Bekam juga mencegah terjadinya peregangan arteri karotis eksternal, dan bekam juga bisa mengeluarkan unsur-unsur kalsium dari otot-otot pembuluh darah otak, sehingga tidak terjadi penyempitan pada pembuluh internal dan tidak terjadi peregangan pada pembuluh eksternal, sehingga tidak terjadi sakit kepala.

Hal ini terbukti pada responden yang dilakukan terapi bekam basah, sistem peredaran darah menjadi lancar, dan mengalami dilatasi, sistem syaraf menjadi relaksasi sehingga skla nyeri dapat menurun.

Terapi bekam basah sangat efektif sebagai terapi non farmakologi yang dapat dilakukan dirumah untuk penurunan skala nyeri migrain. Hal ini terbukti dari 18 responden di Desa Noreh Wilayah Kerja Puskesmas Sreseh, di dapatkan seluruhnya (100\%) mengalami penurunan skala nyeri migrain.

Skala nyeri terhadap migrain dipengaruhi oleh beberapa faktor salah satunya adalah jenis kelamin memiliki pengaruh terhadap skala nyeri migrain. Terbukti sebagian besar responden yaitu 11 responden $(61,11 \%)$ berjenis kelamin perempuan. Perempuan cenderung memiliki sekresi hormon yang lebih tinggi dari pada laki-laki pada waktu tertentu, sehingga metabolisme tubuh meningkat. Ketika perempuan mengalami kondisi kelelahan, stress, saat masahaid, kurang tidur, dan penggunaan kontrasepsi oral hal tersebut dapat memicu semakin beratnya skala nyeri migrain.

Hasil penelitian ini didukung oleh penelitian yang dilakukan oleh 
Suarsyaf (2012), dalam judul penelitian Pengaruh Terapi Bekam Terhadap Perubahan Skala Nyeri Pada Pasien Nyeri Punggung Bawah. Penelitian ini menggunakan desain penelitian cross sectional. Pada 35 responden dengan hasil dimana didapatkan rata-rata skala nyeri pasien sebelum bekam 5,66 \pm 1.765 dan turun menjadi $3 \pm 1,515$ sesudah diberikan bekam $(\mathrm{p}=0,000)$ hasil ini menyimpulkan bahwa terapi bekam berpengaruh terhadap perubahan skala nyeri.

Pada responden yang dilakukan penelitian, dari 11 orang responden yanag berjenis kelamin perempuan, hanya 1 orang yang mengalami penurunan yang signifikan, sedangkan penurunan lainnya banyak terjadi pada jenis kelamin laki-laki. Hal tersebut bisa dipengaruhi akibat metabolism yang meningkat.

Penurunan skala nyeri migrain di pengaruhi oleh faktor usia, dimana sebagian besar yaitu 11 responden $(61,11 \%)$ berusia $26-30$ tahun. Dimana pada usia 26-30 tahun korteks serebri dan sel-sel didalam tubuh masih mampu melakukan fungsinya dengan baik. Sehingga ketika diberikan terapi bekam basah skala nyeri migrain mengalami penurunan (Pradana, 2014). Hal ini terbukti pada 18 responden yang diberikan terapi bekam basah seluruhnya (100\%) mengalami penurunan.

Terapi bekam basah berada pada kategori usia remaja akhir dewasa awal dimana sel-sel tubuh masih dapat menjalankan fungsi dengan baik. Pada saat diberikan terapi bekambasah peredaran darah akan berdilatasi sehingga sistem syaraf juga akan mengalami relaksasi dan skala nyeri mengalami penurunan.

\section{Pengaruh Terapi Bekam Basah Terhadap perubahan Skala Nyeri pada Pasien Migrain di Desa Noreh Wilayah Kerja Puskesmas Sreseh}

Berdasarkan hasil uji statistik Wilcoxon Signed Ranks didapatkan p- value $0,000<\alpha 0,05$ yang berarti menunjukkan bahwa ada perbedaan skala nyeri migrain yang signifikan pada responden yang diberikan Terapi Bekam Basah. Berdasarkan Hasil penelitian selama 14 hari di rumah-rumah pasien migrain dari data yang di dapat di Desa Noreh Wilayah Kerja Puskesmas Sreseh bahwa seluruhnya 18 responden (100\%) pada hasil postest yang diberikan terapi bekam basah mengalami penurunan skala nyeri migrain. Hasil ini menunjukkan bahwa penggunaan terapi bekam basah sangat efektif dalam penurunan skala nyeri migrain pada pasien migrain.

Menurut Suarsyaf (2012), Pada pasien terapi bekam basah dapat meningkatkan sekresi enkefalin dan endofrin. Enkefalin dan Endorfin merupakan opioid endogen yang berfungsi untuk menghambat nyeri. Terdapat tiga golongan utama peptide opioid endogen yang masing-masing berasal dari precursor yang berlainan dan memiliki distribusi anatomik yang sedikit berbeda, yakni golongan enkefalin, beta-endorfin, dan dinorfin. Semua opioid ini bekerja dengan mengikat reseptor opiate sehingga menyebabkan efek analgesik.

Hasil penelitian ini didukung oleh penelitian yang dilakukan oleh Yanti (2012), dalam judul penelitian Pengaruh Terapi Bekam Terhadap Perubahan Skala Nyeri Pada Pasien Nyeri Kepala. Penelitian ini menggunkan rancangan penelitian deskriptif analitik bivariat dan desain penelitiannya eksperimental. Pada 16 responden dengan hasil dimana didapatkan rata-rata skala nyeri pasien sebelum bekam 4,5 $\pm 1,265$ dan turun menjadi 2,69 $\pm 1,401$ setelah diberikan bekam ( $p$ value 0,00) hasil ini menyimpulkan bahwa terapi bekam berpengaruh terhadap perubahan skala nyeri

\section{PENUTUP}

\section{Kesimpulan}


a Ada perbedaan perubahan skala nyeri pada pasien migrain sebelum dan sesudah diberikan terapi bekam basah di Desa Noreh Wilayah Kerja Puskesmas sreseh.

b Ada pengaruh terapi bekam basah terhadap perubahan skala nyeri pada pasien migrain di Desa Noreh Wilayah Kerja Puskesmas Sreseh.

2. Saran
a. Teoritis
1. Bagi
Profesi (Ilmu Keperawatan)

peneliti ini diharapkan dapat menjadi alternatif sterapi komplementer dan informasi tentang terapi bekam basah merupakan salah satu terapi yang dapat menurunkan skala nyeri pada pasien migrain.

2. Bagi Institusi Pendidikan

Skripsi ini diharapkan agar dapat dilakukan penelitian lebih lanjut mengenai terapi bekam yang dapat untuk menghilangkan nyeri kepala pada pasien. Serta perlu dilakukan juga penelitian lebih lanjut mengenai pembekaman pada titik-titik tertentu, untuk memperlihatkan bagaimana titilktitik pembekaman tersebut berefek pada kesehatan pasien.

b. Saran Praktis
1. Bagi Tenaga Kesehatan (Puskesmas)
Hasil Penelitian ini dapat memberi informasi ilmiah serta tambahan sebagai salah satu sarana pengobatan guna meningkatkan kualitas dan layanan kesehatan.

2. Bagi Peneliti Selanjutnya

Hasil penelitian ini bisa dijadikan sumber bacaan data dasar dan acuan serta literature bagi peneliti selanjutnya untuk mengembangkan suatu penelitian yang sama dan untuk peneliti selanjutnya diharapkan untuk menambah dengan jumlah sampel yang lebih besar dan cakupannya lebih luas serta membandingkan pengaruh lainnya pada pasien perubahan skala nyeri.

\section{DAFTAR PUSTAKA}

Ahmadi, M. (2008). Keampuhan Bekam. Cetakan ke-III. Jakarta: Qultum Media

Anurogo. Y. (2012). Pengaruh Terapi Pijat Penyembuhan (Remedial Massage) Terhadap Nyeri Kepala

60 Migren DiDesa Tergo Kecamatan Dawe Kabupaten Kudus.

BPS. (2014). Indikator Kesehatan. Diakses dari https://www.bps.go.id/statictable /2009/03/10/1559/indikatorkesehatan-1995-2017.html

Cao H et.al. (2010). Clinical research evidence of cupping therapy in China: a systematic literature review. BMC Complementary and Alternative Medicine 2010, 10:70

http://www.biomedcentral.com/ 1472-6882/10/70. March 12.

Herlina. (2014). Kualitas Hidup Penderita Migren Di Poliklinik Saraf RSUP Dr. Kariadi Semarang.

Kurniawan, T. (2015). Hubungan Obesitas Dengan Migrain Di Poliklinik Saraf RSUD Dr. Moewardi Surakarta.

Nursalam. (2011). Konsep dan Penerapan Metodologi Peneliian Ilmu Keperawatan Pedoman Skripsi, Tesis, dan Instrumen 
Penelitian Keperawatan. Edisi 2. Jakarta: Salemba Medika.

Nursalam. (2013). Metodologi Penelitian Ilmu Keperawatan. Edisi 3. Jakarta: Salemba Medika.

Pradana, K, (2014). Pengaruh Terapi Akupuntur Terhadap Migrain. Di Klinik Sinergy Mind Health Surakarta. Skripsi. Fakultas Keperawatan Kusuma Husada Surakarta.

Rahma, M. (2012). Pengaruh Terapi Pijat Penyembuhan (Remedial Massage) terhadap Nyeri Kepala Migrain Di Desa tergo Kecamatan Dawe Kabupaten Kudus.

Sharaf, R. A. (2012). Penyakit Dan Terapi Bekamnya (Dasar-Dasar Ilmiah Dan Terapi Bekam. Surakarta: Thibbiar

Suarsyaf, P. (2012). Pengaruh Terapi Bekam Basah Terhadap Perubahan Skala Nyeri Pada Pasien Nyeri Punggung Bawah.

Sujarweni, V. W. (2014). Metodologi Penelitian Keperawatan. Penerbit Gava Media. Klitren Lor GK III / 15 Yogyakarta.

Tarwoto. (2013). Buku Keperawatan Medikal Bedah. CV Sagung Seto. Jakarta

Widada, W. (2011). Buku Terapi Bekam. Penerbit CV. Lubuk Agung. Jl. Pelajar Pejuang 45 No. 123 Bandung

Yanti, R. F. (2012). Pengaruh Terapi Bekam Terhadap Perubahan Skala Nyeri Pada Pasien Dengan Nyeri Kepala Di Klinik afiat.

Zulfikri, (2015). Pengaruh Terapi Bekam Akupunktur Terhadap intensitas Nyeri Pada klien dengan Nyeri Kepala.
Zulkahfli, dkk. (2015). Asuhan Keperawatan Komunitas. Tangerang Selatan: Binarupa Aksara Publis 